ISSN 1392-3196 / e-ISSN 2335-8947

Zemdirbyste-Agriculture, vol. 102, No. 1 (2015), p. 81-86

DOI 10.13080/z-a.2015.102.010

\title{
Plum (Prunus spp.) aphid guild (Hemiptera: Sternorrhyncha, Aphididae) structure in Lithuania: any impact of an alien aphid species?
}

\author{
Rimantas RAKAUSKAS, Jekaterina HAVELKA, Audrius ZAREMBA \\ Vilnius University \\ M. K. Čiurlionio 21/27, Vilnius, Lithuania \\ E-mail: rimantas.rakauskas@gf.vu.lt
}

\begin{abstract}
A comparison of the plum aphid (Hemiptera: Aphididae) guild structure in Lithuania before (1975) and after (2012) the establishment of the invasive aphid species Brachycaudus divaricatae Shaposhnikov, 1956, was performed to investigate the impact of this invasive species on the native species complex. No substantial changes in the native plum aphid species composition, host plant associations and seasonal frequency dynamics were detected. The incorporation of $B$. divaricatae into the plum aphid guild in the eastern Baltic region of Europe was found to have increased the stability of the guild. Such an effect is explainable by the diversification of the guild structure (one more species incorporated in the food chain) and increased effectiveness of the use of resources (cherry plum was underexploited before the invasion of the new aphid species).
\end{abstract}

Key words: Brachycaudus divaricatae, guild structure, invasive alien species, plum aphids.

\section{Introduction}

Aphids (Hemiptera: Sternorrhyncha, Aphididae) are important pests of cultivated plums (Prunus spp.) all over the world (Barbagallo et al., 1997; Blackman, Eastop, 2000; Barbagallo et al., 2007). In Lithuania, distribution, morphology, life cycles and host specificity of plum aphid species have been the subject of intensive studies since the seventh decade of the last century (Rakauskas, Cichocka, 2005, also references therein). Six aphid species have been reported inhabiting plum trees in Lithuania: Hyalopterus pruni (Geoffroy, 1762), Phorodon humuli (Schrank, 1801), Brachycaudus cardui (Linnaeus, 1758), B. helichrysi (Kaltenbach, 1843) and Rhopalosiphum nymphaeae (Linnaeus, 1761). Out of these, $H$. pruni appeared to be the most common one, followed by $P$. humuli (Rakauskas, 1978; 1980). Since 2002, an alien to Central Europe invasive aphid species Brachycaudus divaricatae Shaposhnikov, 1956 has been established in Lithuania (Rakauskas, Cichocka, 2005; Rakauskas, Turčinavičienè, 2006; Bašilova et al., 2012). It is common knowledge that invasive species not only increase in numbers and spread geographically after their introduction into a new area, but might also start threatening the biodiversity of the invaded areas (UNEP, 2002; Mooney, 2005; DAISIE, 2009; Estoup, Guillemaud, 2010). The possible impact of the alien invasive species on the native biota concerns multiple interactions and is not easy to prove unambiguously (Sakai et al., 2001; Roy et al., 2011; Jeschke et al., 2012). Therefore, comparative analysis of native communities before and after the invasion is important both from the theoretical and practical viewpoints.
This study mainly focused on a comparison of the plum aphid guild structure in Lithuania before (1975) and after (2012) the establishment (from 2002) of the invasive alien (to Central Europe) aphid species Brachycaudus divaricatae, using previous studies of plum aphids performed in 1975 (Rakauskas, 1978).

\section{Materials and methods}

The principle data concerning plum aphid guild structure in the absence of an invasive aphid species were those from 1975 (Rakauskas, 1978). In 1975, the observations lasted from 23 May-31 July in northern and eastern parts of Lithuania (Fig. 1). Host plants were visually examined for the presence of any aphids. Degree of infestation was evaluated by assigning one of the four infestation levels, the fourth level being the heaviest one (Rakauskas, 1980). The location of aphid colonies on the tree canopy (root suckers, aerial shoots, leaves, fruits, etc.) was also evaluated. In total, 222 cherry plums (Prunus cerasifera Ehrh.) and 424 domestic plums (P. domestica L.) were investigated in 1975. Aphid species were identified in the field based on the macroscopic characters of aphid colonies (Rupais, 1969). When needed, a precise identification of the sampled aphid material was performed on microscope slides using the keys developed by Shaposhnikov (1964) and Cichocka (1980). Research into the plum aphid guild structure in the presence of the invasive aphid species Brachycaudus divaricatae was performed in 2012 from 9 May to 13 August in 24 administrative regions of Lithuania (Fig. 1). To make the 
results comparable, the same method of evaluating aphid infestation degree was applied. In addition to the earlier mentioned identification keys, those of Blackman and Eastop (2000), also Rakauskas and Cichocka (2005) were used. Samples of the genus Hyalopterus have also been attributed to species by means of their partial sequences of mitochondrial COI gene (Rakauskas et al., 2013). The aphid material is deposited in the aphid collection of the Department of Zoology, Vilnius University. Altogether, 1063 cherry plum and 756 domestic plum trees were investigated in 2012.

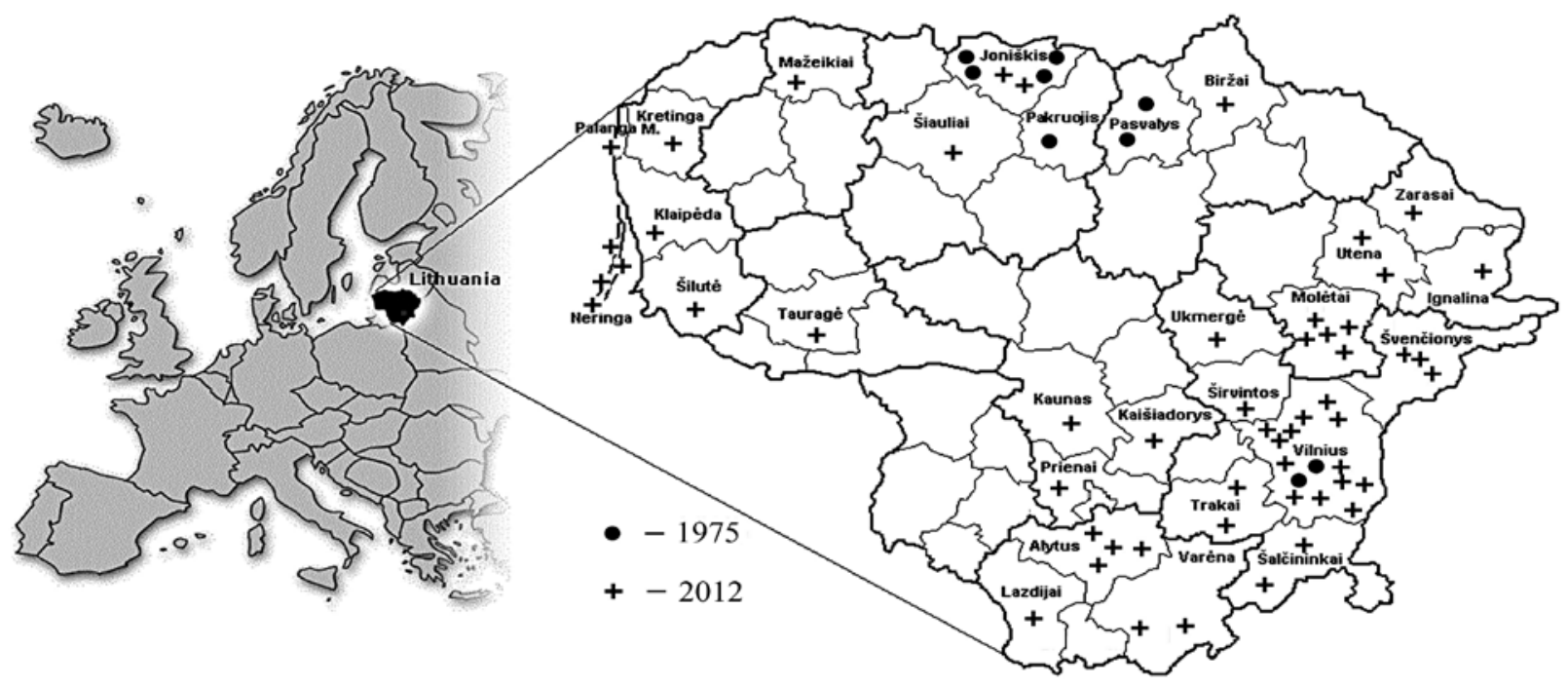

Figure 1. Sampling locations in Lithuania in respective years showing administrative regions wherein the research was performed

Aphid guild structure was evaluated by calculating the percentage of infestation for every aphid species on each host (cherry plum and domestic plum) during the season (May-July). In addition, selected host plants were monitored in 2012 to get more precise information about the seasonal dynamics of aphid infestation for particular plum species. This monitoring was performed on 19 cherry plum trees and 15 domestic plum trees in Skirgiškès (Vilnius region, Lithuania,

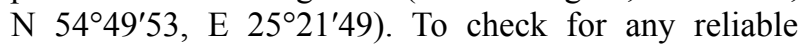
differences in aphid infestation between cherry plum and domestic plum in different years, a nonparametric ANOVA, including Kruskal-Wallis test followed by a post hoc test (multiple comparisons of mean ranks) was performed. Nonparametric statistics were chosen because the data set consisted of nominal and ordinal data. To reveal the most important predictors of plum infestation, multiple regression analysis was carried out. Two types of analyses were carried out for cherry plums: based on data for all aphid species, and with $B$. divaricatae data removed. All computations were performed by means of STATISTICA, version 8 (2007).

\section{Results and discussion}

In 1975, infestation of cherry plums was low (14.41\% trees infested, $10.36 \%$ at infestation stages III to IV). The predominant aphid species inhabiting cherry plums in the studied regions of Lithuania was Hyalopterus pruni (Geoffroy) (12.61\% trees infested, $6.65 \%$ at infestation stages III to IV). Phorodon humuli (Schrank) and Brachycaudus cardui (L.) were each found twice only, whilst $B$. helichrysi (Kaltenbach) was not found on cherry plums at all (Fig. 2 A). In 2012, infestation of cherry plums was much higher $(73.28 \%$ trees infested, $29.78 \%$ at infestation stages III to IV). The predominant aphid species on cherry plums was $B$. divaricatae $(62.84 \%$ trees infested, $26.95 \%$ at infestation stages III to IV). The remaining four aphid species were rare on cherry plums in 2012, the same as in 1975 (Fig. 2 C). Kruskal-Wallis test followed by multiple comparisons post hoc test revealed statistically significant difference in the total infestation of cherry plum between 1975 and 2012, which was mainly caused by the addition of $B$. divaricatae (Table 1). When the information on the infestation by $B$. divaricatae had been removed from the data set, the total infestation of cherry plums did not show any statistically significant differences between 1975 and 2012 (Table 1).

This was also confirmed by the multiple regression analysis (Table 3 ). That is, a marked increase in the total infestation of cherry plums by all aphid species between 1975 and 2012 is explainable by the introduction of $B$. divaricatae. On domestic plum, the infestation level of $H$. pruni was remarkably high in 1975 (41.75\% trees infested, 15.57\% infested at levels III-IV), and constituted half of the aphid species detected on domestic plums, followed by P. humuli (Fig. 2 B). H. pruni was very common also in $2012(46.36 \%$ trees infested, $26.62 \%$ infested at levels III-IV), followed by $B$. helichrysi, B. cardui, P. humuli and R. nymphaeae (Fig. 2 D).

Kruskal-Wallis test followed by multiple comparisons post hoc test did not reveal any statistically significant difference between the total infestation on $P$. domestica between 1975 and 2012, although differences in infestation levels by $P$. humuli and $H$. pruni proved to be statistically significant (Tables 2-3). 
A Prunus cerasifera, 1975

(32 colonies, 222 trees)

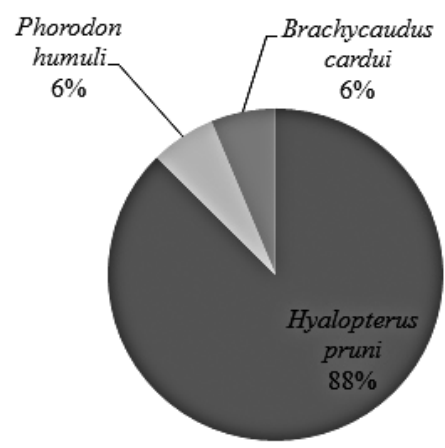

C Prunus cerasifera, 2012 (779 colonies, 1063 trees)

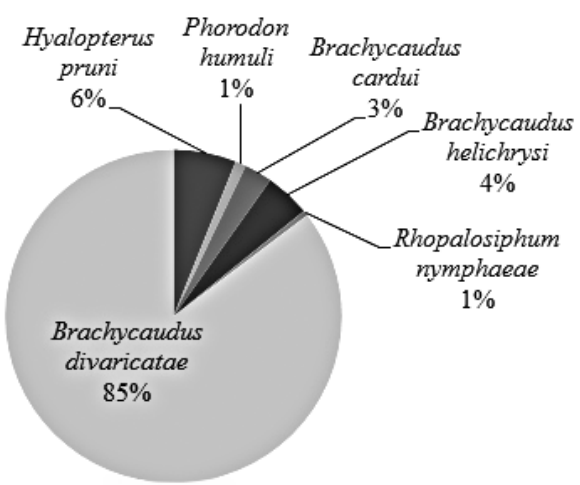

B

Prunus domestica, 1975

(352 colonies, 424 trees)

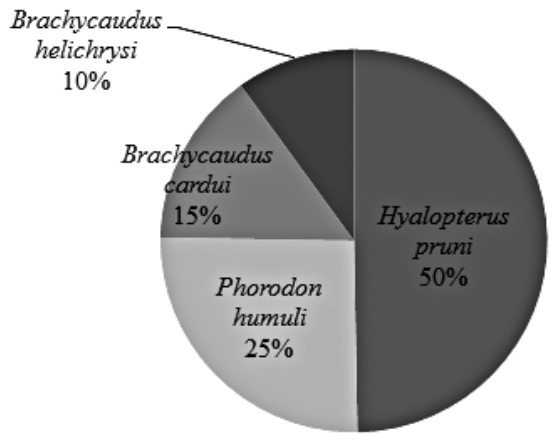

D

Prunus domestica, 2012

(511 colonies, 756 trees)

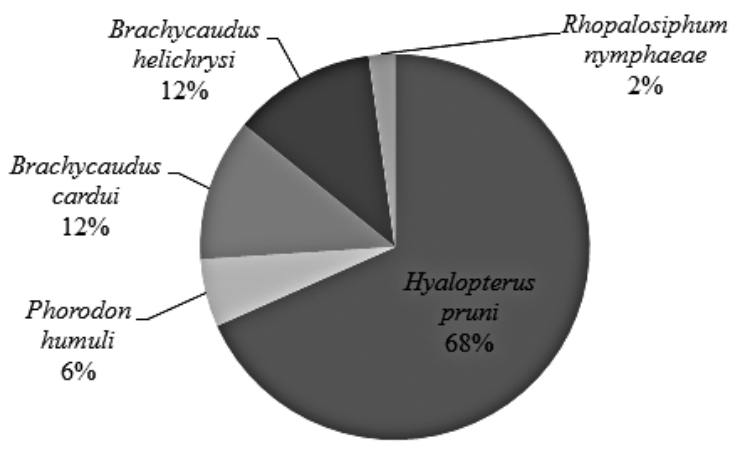

Note. Numbers of overall aphid colonies registered and plum trees investigated are given for every plum species each year.

Figure 2. Plum aphid (Hemiptera: Aphididae) guild structure (\% of different aphid species registered on two plum species) in Lithuania before (1975) and after (2012) the invasion of Brachycaudus divaricatae

Table 1. The results of Kruskal-Wallis test and multiple comparisons of mean ranks post hoc test for the total infestation of cherry plum and the infestation levels by particular aphid species

\begin{tabular}{lcccc}
\hline \multirow{2}{*}{ Aphid species inhabiting Prunus cerasifera } & Kruskal-Wallis test & \multicolumn{2}{c}{ Multiple comparison } \\
\cline { 2 - 5 } & $\mathrm{H}(1, \mathrm{~N}=1285)$ & $p$ & $z^{\prime}$ & $p$ \\
\hline Brachycaudus divaricatae & $\mathbf{2 4 5 . 5 0 3}$ & $\mathbf{0 . 0 0 0}$ & $\mathbf{1 4 . 6 7 8}$ & $\mathbf{0 . 0 0 0}$ \\
B. cardui & 1.230 & 0.267 & 0.255 & 0.799 \\
B. helichrysi & 7.287 & 0.007 & 0.751 & 0.453 \\
Hyalopterus pruni & $\mathbf{2 4 . 0 4 8}$ & $\mathbf{0 . 0 0 0}$ & $\mathbf{1 . 9 9 3}$ & $\mathbf{0 . 0 4 6}$ \\
Phorodon humuli & 0.051 & 0.821 & 0.0345 & 0.973 \\
Rhopalosiphum nymphaeae & 0.837 & 0.360 & 0.089 & 0.930 \\
\hline \multicolumn{1}{c}{ Total infestation (including B. divaricatae) } & $\mathbf{2 1 2 . 4 1 5}$ & $\mathbf{0 . 0 0 0}$ & $\mathbf{1 2 . 4 7 9}$ & $\mathbf{0 . 0 0 0}$ \\
\hline \multicolumn{1}{c}{ Total infestation (B. divaricatae excluded) } & 2.73 & 0.098 & 0.875 & 0.381 \\
\hline
\end{tabular}

Note. Statistically significant differences between 1975 and 2012 supported by multiple comparisons of mean ranks post hoc test are given in bold.

Table 2. The results of Kruskal-Wallis test and multiple comparisons of mean ranks post hoc test for the total infestation of domestic plum and the infestation levels by particular aphid species

\begin{tabular}{lcccc}
\hline \multirow{2}{*}{ Aphid species inhabiting Prunus domestica } & \multicolumn{2}{c}{ Kruskal-Wallis test } & \multicolumn{2}{c}{ Multiple comparison } \\
\cline { 2 - 6 } & $\mathrm{H}(1, \mathrm{~N}=1180)$ & $p$ & $z^{\prime}$ & $p$ \\
\hline Brachycaudus cardui & 5.590 & 0.018 & 1.207 & 0.228 \\
B. helichrysi & 0.010 & 0.919 & 0.048 & 0.962 \\
Hyalopterus pruni & $\mathbf{9 . 6 5 8}$ & $\mathbf{0 . 0 0 2}$ & $\mathbf{2 . 8 1 6}$ & $\mathbf{0 . 0 0 5}$ \\
Phorodon humuli & $\mathbf{8 9 . 0 6 4}$ & $\mathbf{0 . 0 0 0}$ & $\mathbf{4 . 9 2 3}$ & $\mathbf{0 . 0 0 0}$ \\
Rhopalosiphum nymphaeae & 6.223 & 0.013 & 0.416 & 0.678 \\
\hline \multicolumn{1}{c}{ Total infestation } & 0.689 & 0.407 & 0.704 & 0.481 \\
\hline
\end{tabular}

Note. Statistically significant differences between 1975 and 2012 supported by multiple comparisons of mean ranks post hoc test are given in bold. 
In $2012, B$. divaricatae was found on cherry plums throughout the entire evaluation period. B. cardui and $H$. pruni stayed on monitored cherry plums until 18 July. P. humuli and $R$. nymphaeae declined in abundance from mid-June and disappeared by the $5^{\text {th }}$ of July (Fig. 3 A). On monitored domestic plums, $H$. pruni was present until the end of August, $P$. humuli - until 18 June, whilst remaining species disappeared by the end of June (Fig. 3 B). Similar results emerged during the field observations of 2012: B. divaricatae was present on cherry plums throughout the entire evaluation period, whilst other species disappeared by the end of June. Single findings of $H$. pruni were on 10 July and 13 August. Field observations of 2012 on domestic plums revealed the presence of $H$. pruni until the end of August; other species disappeared by the end of June. In field observations of $1975, H$. pruni occurred on cherry plums till the end of July, B. cardui and P. humuli - in May only. In the same year on domestic plums, $H$. pruni, B. cardui and $P$. humuli occurred till the end of July, whilst $B$. helichrysi disappeared by the end of June. In both years, $H$. pruni and $P$. humuli mostly inhabited leaves of the two species of plum, whilst Brachycaudus species preferred young shoots, including fresh foliage.

The available data show the same native aphid species having inhabited plums in Lithuania before (Rakauskas, 1978; 1980) and after invasion of B. divaricatae (Rakauskas, Cichocka, 2005; and the present study). The multiple regression model obtained for the infestation of cherry plum (excluding data on $B$. divaricatae) is statistically significant (Table 3 , summary), and the value of $R^{2}$ is 0.804 . When data on $B$. divaricatae were excluded from analysis, the following statistically significant independent variables according to the values of beta appeared among the most important predictors: the infestation by $H$. pruni, by $B$. helichrysi and by $B$. cardui (Table 3). That is, $H$. pruni was the most common native aphid species inhabiting cherry plums before the arrival of $B$. divaricatae, and it remained so afterwards. The alien invasive aphid species seems to have occupied underexploited cherry plum. The principle winter host
A Infestation of Prunus cerasifera (19 trees monitored)
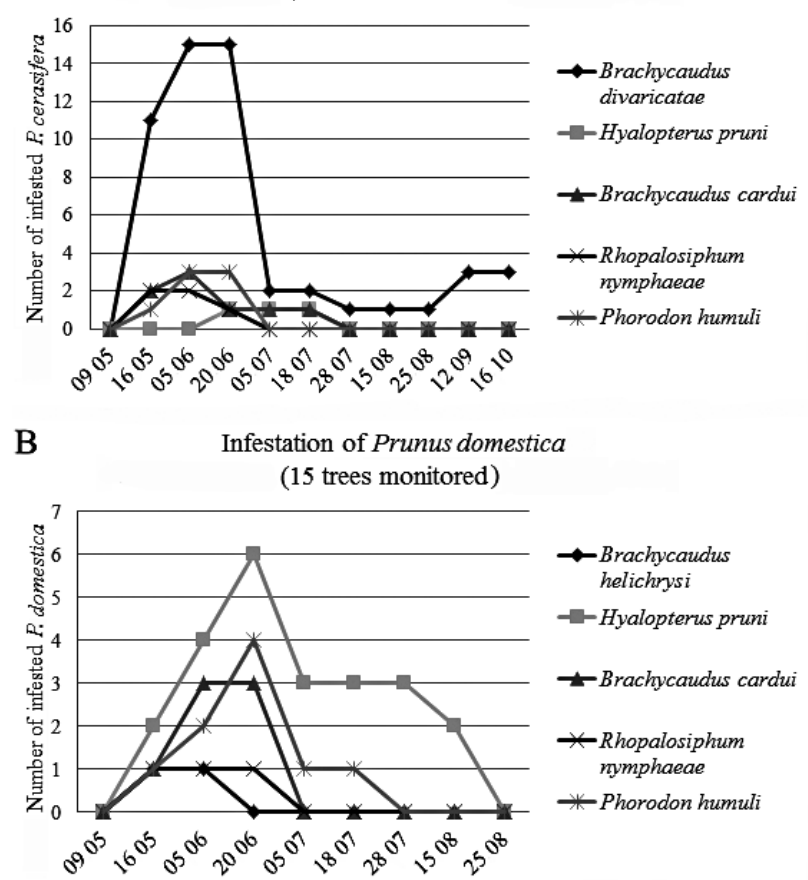

Figure 3. Seasonal dynamics of aphid infestation on monitored plums Prunus cerasifera and P. domestica in Skirgiškès, Vilnius region, Lithuania in 2012

for the guild of the native plum aphid species before and after invasion of $B$. divaricatae remained domestic plum. The multiple regression model obtained for the infestation of domestic plum is statistically significant (Table 3, summary) and the value of $R^{2}$ is 0.675 . The most important predictor of the total infestation of domestic plum appears to be the infestation level by H. pruni (Table 3 ).

The possible explanation is that the cherry plum is an invasive plant species in Central and Western Europe (Meusel et al., 1965). Since the introduction of cherry plum in Lithuania in the middle of the last century, native plum aphid species failed to change their feeding

Table 3. The results of multiple regression analysis

\begin{tabular}{|c|c|c|c|c|c|c|}
\hline & \multicolumn{4}{|c|}{ Prunus cerasifera } & \multicolumn{2}{|c|}{ Prunus domestica } \\
\hline & \multirow{2}{*}{\multicolumn{2}{|c|}{$\begin{array}{c}\text { Including } \\
\text { Brachycaudus divaricatae } \\
R=0.847, R^{2}=0.717 ; \\
\text { adjusted } R^{2}=0.7147 ; \\
\mathrm{F}(11,1273)=293.07 \\
p<0.00070 ; \\
\text { SE of estimate: } 0.2647\end{array}$}} & \multirow{2}{*}{\multicolumn{2}{|c|}{$\begin{array}{c}\text { Brachycaudus divaricatae } \\
\text { excluded } \\
R=0.897, R^{2}=0.804 ; \\
\text { adjusted } R^{2}=0.803 ; \\
\mathrm{F}(10,1274)=522.78 \\
p<0.000 ; \\
\text { SE of estimate: } 0.136\end{array}$}} & \multirow{2}{*}{\multicolumn{2}{|c|}{$\begin{array}{c}R=0.821, R^{2}=0.675 \\
\text { adjusted } R^{2}=0.672 ; \\
\mathrm{F}(10,1168)=242.16 \\
p<0.0000 ; \\
\text { SE of estimate: } 0.286\end{array}$}} \\
\hline $\begin{array}{l}\text { Summary of multiple } \\
\text { regression analysis }\end{array}$ & & & & & & \\
\hline Variables & beta & $p$-level & beta & $p$-level & beta & $p$-level \\
\hline Year & 0.251 & 0.000 & 0.060 & 0.001 & -0.081 & 0.008 \\
\hline Month & -0.114 & 0.000 & -0.028 & 0.084 & -0.145 & 0.000 \\
\hline Day & -0.144 & 0.000 & 0.045 & 0.001 & -0.027 & 0.246 \\
\hline Place & $-\mathbf{0 . 1 8 9}$ & 0.000 & 0.005 & 0.735 & 0.022 & 0.491 \\
\hline Plant height & 0.046 & 0.005 & -0.005 & 0.731 & -0.011 & 0.523 \\
\hline Infestation level by $B$. divaricatae & 0.710 & 0.000 & - & - & - & - \\
\hline Infestation level by Hyalopterus pruni & 0.241 & 0.000 & 0.673 & 0.000 & 0.742 & 0.000 \\
\hline Infestation level by $B$. helichrysi & 0.168 & 0.000 & 0.382 & 0.000 & 0.138 & 0.000 \\
\hline Infestation level by Phorodon humuli & 0.011 & 0.504 & 0.117 & 0.000 & 0.072 & 0.000 \\
\hline Infestation level by $B$. cardui & 0.150 & 0.000 & 0.329 & 0.000 & 0.200 & 0.000 \\
\hline $\begin{array}{l}\text { Infestation level by } \\
\text { Rhopalosiphum nymphaeae }\end{array}$ & 0.031 & 0.050 & 0.089 & 0.000 & 0.057 & 0.001 \\
\hline
\end{tabular}

Note. SE - standard error; statistically significant $(p<0.05)$ standardized regression coefficients B (beta) are given in bold. 
preferences and therefore mainly feed on domestic plum. Infestation of cherry plums by the predominant native plum aphid species $H$. pruni was low both in 1975 and 2012. Infestation of domestic plums by $H$. pruni during the same period was much higher. Other common local aphid species (B. cardui, B. helichrysi and P. humuli) were also mostly associated with domestic plum in both years. The native aphid species frequency spectrum on both species of plum appeared similar before and after the invasion of $B$. divaricatae: $H$. pruni was predominant, B. cardui, B. helichrysi and P. humuli-subdominant, with $R$. nymphaeae being a rare species (Fig. 2). Available data suggest that $B$. divaricatae has occupied the vacant niche on cherry plums in Lithuania. Such a "peaceful" incorporation of $B$. divaricatae into the plum aphid guild of Lithuania might be explained by the biological peculiarities of Lithuanian populations of the invasive species - they were reported to be monophagous and monoecious on cherry plum (Rakauskas, Juronis, 2006; Rakauskas, Turčinavičienè, 2006). The facultatively shortened life cycle, when laying of overwintering eggs begins in June (for details see Rakauskas and Turčinavičienè, 2006), causes (together with response of host plant and pressure of aphidophages) the decline in abundance of $B$. divaricatae from the mid-summer (Fig. 3 A) thus preventing overexploitation of the host plants and escaping from natural enemies. An important feature of $B$. divaricatae is that winged viviparous females can colonize new cherry plum plants, whereas winged viviparous females of all local plum aphid species leave plums for summer host plants; they are not capable of feeding and reproducing on plums (Smolarz, 1970; Rakauskas, 1983; Mosco et al., 1997). As a consequence, population densities of the native aphid species on cherry plums decline at the end of summer in Lithuania, giving additional feeding space for $B$. divaricatae. The only exception is $H$. pruni, which continues producing apterous viviparous females until the end of summer in some years in certain localities.

Besides the temporal heterogeneity, plums provide also a spatially heterogeneous environment for aphid feeding, as was already referred to for aphid associations on other host plants (Addicot, 1978; Hajek, Dahlsten, 1986; Völkl, 1989; Molnár et al., 2000). Namely, the two most common plum aphid species in Lithuania share their feeding space: $B$. divaricatae mostly inhabits young shoots, including fresh foliage, whilst $H$. pruni prefers leaves. Of the remaining species, young shoots are also preferable for $B$. helichrysi, B. cardui and R. nymphaeae. The latter native aphid species escape confrontation with $B$. divaricatae due to early migration (Fig. 3). Also, as noted earlier, their preferred winter host plant species in Lithuania is domestic plum; they can also live on other plum species, including apricots, peaches and almonds (Cichocka, 1980; Barbagallo et al., 1997; Blackman, Eastop, 2000; Holman, 2009). B. divaricatae, at least for the present in Lithuania and the entire eastern Baltic region of Europe, is monophagous on cherry plum. The other hosts of this species in Lithuania are Prunus americana Marsh (a rare, introduced species) and a cultivated variety 'Skoroplodnaya', which is reported (Eremin, 2003) to be a hybrid between Prunus salicina Lindl. and P. americana. For the present, these plum species seem to be just temporary summer hosts of $B$. divaricatae, without any possibility of aphids completing their entire life cycle on them (Rakauskas, 2013, unpublished data).
Conclusively, the incorporation of $B$. divaricatae into the plum aphid guild of the eastern Baltic region of Europe might be taken as a positive event increasing the stability of the guild. Such an effect can be explained by the increase of the variety of the guild structure (one more species incorporated in the food chain) and more effective use of resources (cherry plum was underexploited before the invasion of the new aphid species). From the viewpoint of horticulture, invasion of $B$. divaricatae might stabilise population dynamics of the native pest aphid species on plums. This is because numerous populations of the invasive aphid species (exploiting cherry plum which is an invasive species of little commercial value for the present at least) serve as an important reservoir for the aphid natural enemies, which subsequently switch to the native aphid populations. Yet, such a speculation demands further research.

\section{Conclusions}

1. No substantial changes in the native plum aphid species composition, host plant associations and seasonal frequency dynamics were detected after the introduction of the alien plum aphid species Brachycaudus divaricatae into Lithuania.

2. B. divaricatae is monophagous on cherry plum in Lithuania, the plum species that is underexploited by the native plum aphid species.

3. Invasion of $B$. divaricatae is expected to stabilise population dynamics of the native pest aphid species on plums, because numerous populations of the invasive aphid species serve as an important reservoir for the aphid natural enemies.

\section{Acknowledgments}

This material is based upon the work supported by the Research Council of Lithuania under grant No. LEK-04/2012.

Received 12052014

Accepted 13112014

\section{References}

Addicot J. F. 1978. Niche relationships among aphids feeding on fireweed. Canadian Journal of Zoology, 56: 1837-1841 http://dx.doi.org/10.1139/z78-250

Barbagallo S. P., Cravedi E., Pasqualini E., Patti I. 1997. Aphids of the principal fruit-bearing crops. Milan, Italy, p. 57-78

Barbagallo S. P., Cocuzza G., Cravedi P., Komazaki S. 2007. IPM case studies: deciduous fruit trees. van Emden H. F., Harington R. (eds). Aphids as crop pests. Wallingford, UK, p. 651-662

Bašilova J., Havelka J., Rakauskas R., Stary P., Turčinavičienè J. 2012. New information on the invasive to Europe aphid species Brachycaudus divaricatae Shaposhnikov, 1956 (Hemiptera: Aphididae). Biologia (Bratislava). 67 (5): 959-965 http://dx.doi.org/10.2478/s11756-012-0083-0

Blackman R. L., Eastop V. F. 2000. Aphids on the world's crops: an identification and information guide. Chichester, UK, p. 247-333

Cichocka E. 1980. Aphids on horticultural plants of Poland. Panstwowe wydawnictwo naukowe, Warszawa, Poland, p. 40-61 (in Polish)

DAISIE 2009. Handbook of alien species in Europe. Dordrecht, the Netherlands

Eremin G. V. 2003. Plums and cherry plum. Kharkov, Ukraine, p. 1-37 (in Russian) 
Estoup A., Guillemaud T. 2010. Reconstructing routes of invasion using genetic data: why, how and so what? Molecular Ecologv. 19: 4113-4130 http://dx.doi.org/10.1111/j.1365-294X.2010.04773.x

Hajek A. E., Dahlsten D. L. 1986. Coexistence of three leaffeeding aphids (Homoptera) on Betula pendula. Oecologia (Berlin). 68: 380-386 http://dx.doi.org/10.1007/BF01036743

Holman J. 2009. Host plant catalogue of aphids - Palaearctic region. Berlin, Germany, p. $189-536$

Jeschke J. M, Gómez Aparicio L., Haider S., Heger T., Lortie C. J., Pyšek P., L. Strayer D. L. 2012. Support for major hypotheses in invasion biology is uneven and declining. NeoBiota. 14: 1-20 http://dx.doi.org/10.3897/neobiota.14.3435

Meusel H., Jäger E., Weinert E. 1965. General chorology of central European flora. Jena, Germany, 279 p. (in German)

Molnár N., Kovács É., Gallé L. 2000. Habitat selection of anttended aphids on willow trees. Tiscia, 32 : $31-34$

Mooney H. A. 2005. Invasive alien species: the nature of the problem. Mooney H. A. et al. (eds). Invasive alien species: a new synthesis. Washington, USA, p. 1-15

Mosco M. C., Arduino P., Bullini P., Barbagallo S. 1997. Genetic heterogeneity, reproductive isolation and host preferences in mealy aphids of the Hyalopterus pruni complex (Homoptera. Aphidoidea). Molecular Ecologv. 6: 667-670 http://dx.doi.org/10.1046/j.1365-294X.1997.00234.x

Rakauskas R. 1978. Dendrophilous aphides in the gardens of South-East and North Lithuania. Nauchnye trudy vyschych uchebnych zavedenij Litovskoj SSR, ser. Biologija, 16 (2): 53-57 (in Russian)

Rakauskas R. 1980. Aphides on fruit-trees and fruit-bearing shrubs of South-East Lithuania. Trudy akademii nauk LitSSR, ser. B, 2 (90): 33-44 (in Russian)

Rakauskas R. 1983. Biology of the mealy plum aphid and its natural enemies in Lithuania. Rupais A. A. et al. (eds). Taxonomy and ecology of pest aphids: proceedings of all union aphidological symposium. Riga, Latvia, p. 57-58 (in Russian)

Rakauskas R., Cichocka E. 2005. Aphids inhabiting Prunus in the Eastern Baltic region: present state of knowledge and prospective research. Aphids and other Hemipterous Insects, 11: 141-152

Rakauskas R., Juronis V. 2006. Brachycaudus divaricatae Shaposhnikov (Hemiptera: Aphididae): changes in host specificity pose a new threat to plum farming. Acta Zoologica Lituanica, 16 (1): 61-66

http://dx.doi.org/10.1080/13921657.2006.10512711

Rakauskas R., Turčinavičienè J. 2006. Brachycaudus divaricatae Shaposhnikov, 1956 in Europe: biology, morphology and distribution, with comments on its taxonomic position (Hemiptera, Sternorrhyncha: Aphididae). Mitteilungen aus dem Museum für Naturkunde in Berlin, Zoologische Reihe. 82 (2): 248-260 http://dx.doi.org/10.1002/mmnz.200600011

Rakauskas R., Havelka J., Zaremba A. 2013. COI and morphological specificity of the mealy aphids (Hyalopterus spp.) collected from different hosts in Europe (Hemiptera: Anhididae). ZooKevs, 319: 255-267 http://dx.doi.org/10.3897/zookeys.319.4251

Roy H. E., Roy D. B., Roques A. 2011. Inventory of terrestrial alien arthropod predators and parasites established in Eurone. BioControl, 56: 477-504 http://dx.doi.org/10.1007/s10526-011-9355-9

Rupais A. 1969. Atlas of the Baltic dendrofilous plantlice: plantlice of leaf-bearing trees and shrubs. Riga, Latvia, p. 347-348 (in Russian)

Sakai A. K., Allendorf F. W., Holt J. S., Lodge D. M., Molofsky J., With K. A., Baughman S., Cabin R. J., Cohen J. E., Ellstrand N. C., McCauley D. E., O’Neil P., Parker I. M., Thompson J. N., Weller S. G. 2001. The population biology of invasive species. Annual Review of Ecology and Systematics. 32: 305-332

http://dx.doi.org/10.1146/annurev.ecolsys.32.081501.114037

Shaposhnikov G. Kh. 1964. Suborder Aphidinea aphids (keys). Bey-Bienko G. Ya. (ed.). Keys to the insects of the European part of the USSR, vol. I. Moskva, Leningrad, p. 489-616 (in Russian)

Smolarz S. 1970. Biology of the mealy plum aphid Hyalopterus pruni (Geoff.) (Homoptera, Aphidoidea). Bulletin Entomologique de Pologne, 40 (2): 287-328

STATISTICA for Windows (computer program manual). 2007. StatSoft Inc., Tulsa, USA

UNEP 2002. United Nations Environmental Programme COP 6 Decision VI/23. Alien species that threaten ecosystems, habitats or species. Hague, the Netherlands

Völkl W. 1989. Resource partitioning in a guild of aphid species associated with creeping thistle Cirsium arvense. Entomologia Exnerimentalis et Annlicata. 51: 41-47 http://dx.doi.org/10.1111/j.1570-7458.1989.tb01212.x

\title{
Slyvos (Prunus spp.) amaru gildijos (Hemiptera: Sternorrhyncha, Aphididae) struktūra Lietuvoje: ar jai turi įtakos svetimkraštė amarų rūšis?
}

\author{
R. Rakauskas, J. Havelka, A. Zaremba \\ Vilniaus universitetas
}

\section{Santrauka}

Siekiant ịvertinti svetimkraštės amarų rūšies Brachycaudus divaricatae (Shaposhnikov, 1956) ịtaką vietinèms slyvų amaru rūšims (Hemiptera: Aphididae), buvo palyginta slyviniu amarų gildijos sudètis Lietuvoje 1975 (iki 2002 m. pasirodant svetimkraštei amarų rǔšiai) ir 2012 metais. Vietinių amarų rūšių kokybinis ir kiekybinis spektras, mitybinė specializacija ir sezoninè dinamika abiem tyrimų laikotarpiais esmingai nesiskyrè. Darytina išvada, jog svetimkrašte amarų rūšis padidino slyvinių amarų gildijos stabilumą Lietuvoje, nes mitybinėje grandinėje atsirado papildoma rūšis, kuri padidino mitybinių resursų panaudojimo efektyvumą (iki jai pasirodant vietinės amarų rūšys menkai maitinosi ant skėstašakės slyvos).

Reikšminiai žodžiai: Brachycaudus divaricatae, gildijos struktūra, slyvų amarai, svetimkraštè rūšis. 